International Journal of Language Education

Volume 5, Number 4, 2021, pp. 372-381

ISSN: $2548-8457$ (Print) 2548-8465 (Online)

Doi: https://doi.org/10.26858/ijole.v5i4.23598

\title{
Language Use in EFL Classroom Interaction: A Sociolinguistic Study
}

\author{
Sherli Agustine \\ University of Palangka Raya, Indonesia \\ Email: sherliagustine.sa@gmail.com \\ Natalina Asi \\ University of Palangka Raya, Indonesia \\ Email:natalina@edu.upr.ac.id \\ Maria Arina Luardini \\ University of Palangka Raya, Indonesia \\ Email:maria_luardini@edu.upr.ac.id
}

Received: 17 September 2021

Reviewed: 28 September 2021-30 October 2021

Accepted: 6 December 2021

\begin{abstract}
Society and language cannot be separated, both have a relationship where society can be formed by the language they use. The diversity of languages used by teachers and students in EFL classroom interaction represents the existence of a bilingual or multilingual community. This research was conducted to describe how is the language use in EFL classroom interaction. The type of this research was descriptive research using the qualitative method. The subject were one of the English teachers and the students of the eleventh grade of MAN Katingan. The data collection was done by questionnaire using a google form to students and interview was done to the English teacher. The result showed the use of language at MAN Katingan in EFL classroom interaction was varied enough. Based on the students' view, teacher and students used $24,7 \%$ English, 40,4\% Indonesian, 8,4\% Banjarese, 0,9\% Dayakese, and 26,2\% mixed the language or used code-switching and code-mixing in EFL classroom interaction. On the other hand, the teacher stated that she mostly used code-switching and code-mixing. Sometimes, she used the local language to interact with the students in her EFL classroom.
\end{abstract}

Keywords: language use; EFL; classroom interaction; sociolinguistics study

\section{Introduction}

The interaction of two or more languages in society will encourage humans to determine language attitudes. Language attitudes arise because people who speak the language have a goal to achieve. In line with this, Charolina (2020) in her research pointed out that language selection is not random but determined by social, cultural, and contextual factors. It happens because the speaker has a goal to achieve. The language used must resemble to the ongoing speech situation.

Language plays a vital role in human life-individuals to express their thoughts and emotions, meet and communicate with everyone, and also establish and maintain social 
relationships between them. These may occur in different spaces used by language. The use of language can be part of the ethnographic discourse of communication, to examine the relationship between language and society, and how multilingual speakers use language in their discourse community environment.

Family environment, community environment, and school environment play a very important role in learning the human language (Charolina, 2020). Whereas, the daily language choices used by students in EFL classroom interaction depend on the background of the students' speech. This is also the student and teacher of MAN Katingan faces in the EFL classroom interaction. MAN Katingan is one of Islamic school in Katingan Regency, Central Kalimantan. In general, MAN Katingan has major tribes which are Dayakese and Banjarese. As a bilingual, students and teachers of MAN Katingan often face the choice of language to interact in the EFL classroom.

In MAN Katingan's EFL classroom interaction, the diversity of languages used by students represents the existence of bilingual or multilingual communities. They can choose multiple languages for them to learn. However, it is precisely the choice of language that affects each other during use. This situation guided them to choose the language used by teachers and students in the EFL classroom interaction.

The ethnic diversity in MAN Katingan may indirectly affect the language choices a student or teacher when speaking in an EFL classroom. Most of the population of MAN Katingan are the Dayak and Banjar tribes. They are bilingual. They have two languages, namely the mother tongue of the respective speakers and Indonesian as the second language. They will use these languages as needed.

According to the survey results of daily conversations, teachers and students of MAN Katingan are usually accustomed to using two or more languages when communicated. This may be affected by social and contextual factors, that is social and contextual factors affect the appearance of language variation. In some cases, the use of more than one language will cause the language environment of the speech partner to be very complicated. They must be able to speak the language to match with their speech partner. Language speakers in MAN Katingan can choose the language to determine which language will be used in the communication. Whether it is between teachers and teachers, between teachers and students, or between classmates. So, this research is conducted to know how is the language use in EFL classroom interaction at MAN Katingan. Are they use full English or codeswitching and codemixing?

\section{Literature review}

In principle, language has information function, question function and command function. Finocchiaro develops language functions into six functions: (a) personal function, (b) interpersonal communication Function, (c) Command function, (d) Reference function, (e) Metalanguage function and (f) Imagination function. People in the speech community use a language to meet their needs in life; they use language for interaction. In other words, language plays a very important role in human life-people use language to express their thoughts and emotions, to satisfy their own needs or desires, to communicate everything with others, to establish and maintain a society between people relation. them. These may occur in various areas of language use. Language use is part of it. Discuss the ethnography of communication, discuss the relationship between language and society, and how multilingual users use language in their language community environment (Muin, 2019). 
A language is an essential part of human lives. It is used as a means of communication and interaction. Human beings may speak only in one language (his native language); they may speak two languages (native and national language); and they may have mastery of more than two languages (native, national, and foreign languages).

Language can be studied by its use and functions. Language use is not only be apart by culture, age, social status, and gender but also depends on the situation around. Based on Mu'in (2019) there are five strategies of communication in the norms of communication. First strategy shows that "a speaker should know what he wants to say, and to whom he conducts a communication and interaction." Second strategy is related to a language choice, "what language or varieties of language is (are) appropriate in the socio-cultural setting where the communication or interaction happens". Third strategy is in line with "when and how we use turns in speaking, interrupt when the other is speaking." Fourth strategy is the time to keep silent e.g., "when we should keep silent." Fifth strategy is about quality of voice and attitudes, e.g., "how well our voice is, and how good our attitudes are in the acts of speaking." All the strategies are meant to produce utterances followed by respectful and polite attitudes. The utterances produced are expected to be culturally acceptable for the participants involved in interpersonal communication.

More, he stated "A language use is controlled by linguistic etiquette. This linguistic etiquette refers to the practice in any speech community of organizing linguistic action so that it is seen as appropriate to the current communicative event". In this case, language use is how the language is used in communication depends on the speech partner. People use only one language in communicating with others when they are in monolingual society. Meanwhile, people use two or more languages or codes in bilingual society. This study aims to analyze some of the sociolinguistic patterns of language use in bilingual or multilingual situations.

In Indonesia, English is entirely as a foreign language. Some researchers such as Sharaeai (2012) and Snorrad (2014) have studied the use of language in teaching and learning foreign languages in the classroom. The results showed there are some reasons why students use first language in English classroom. It also helps teachers and students may be able to reduce them to improve the English language learning process. Teachers can also adjust their classroom management to reduce the amount and frequency for first language use.

In addition, Asrifan (2021) in his research stated that studying a speech in teaching and learning process in the classroom is interesting topic. The teachers have a challenge to make students understand and achieve the purpose of learning English, but many teachers say that one way to use it is to modify the words in the teacher's speech to speed up the generation of famous words and sentences.

Furthermore, Surayatika (2020) summarized some studies carried out by Atkinson (1987), Schweers (1999), and Nation (2003), based on statement of Bouangeune (2009). There are some reasons for Students' L1 Use in EFL Classroom. The result of those three researchers is due to seven reasons of the use of students' first language as a tool in language learning classroom. It is more natural to communicate in the first language of the students in the L2 class, especially for people with similar native languages. Integrating the students' L1 into the L 2 class is more effective and easier for students and teachers to communicate in the classroom. The mother tongue of the students in the L2 classroom helps teachers manage tasks and help teachers transfer tasks including establishing a common understanding of the text. The use of students' mother tongue (L1) will help teachers promote classroom activities, especially in delivering a complex task. It can also help students focus on the vocabulary and grammar items of the target language. Students' mother tongue lays the foundation for learners, especially the structure of the target language. She believed 
that using L1 in L2 classrooms provides a sense of security and verifies students' life experience. And allow them to express themselves.

\section{Research method}

Research design

The type of this research is descriptive research using qualitative approach based on sociolinguistics perspective. Qualitative research aims to delve into the research environment in order to gain insight into the nature of things, why they are so, and how the participants in the context perceive them (Hill, 2015).

Data collection and instruments

In this research, the subjects are one of the English teachers and students of eleventh grade of MAN Katingan. The qualitative method is used to achieve the research goals which questionnaire was used as a tool to obtain data. More, the interview was done with the English teacher to describe how is the language use in EFL classroom interaction. When obtaining data, this research used a questionnaire using google form. The students were given a questionnaire about teachers' and students' language preferences in English classroom.

\section{Data analysis}

The data of this research is analyzed qualitatively. The researcher gives a questionnaire to the students. There were 10 questions in the questionnaire related to the use of language in English classroom. Then, the researcher interviews some questions to the English teacher which were used to categorize the teacher and students' perception of language use in the English classroom. Last, the data of all instruments are transcribed, analysed, and interpreted.

\section{Findings}

Students' views

There are of 58 students participated in filling the questionnaire. Based on the research question which was aimed to find how is the language use in the English teaching-learning process in EFL classroom, the finding had been supported by the analysis of the data gained from the questionnaire. The result from the questionnaire can be seen from the table below.

Table 1. The result of the questionnaire by students

\begin{tabular}{lccccc}
\hline \multicolumn{1}{c}{ Question } & English & Indonesian & Banjarese & Dayakese & Mix \\
\hline $\begin{array}{l}\text { What language does } \\
\text { your teacher often } \\
\text { use for opening the } \\
\text { lesson? }\end{array}$ & $54 \%$ & $29,3 \%$ & $1,7 \%$ & $0 \%$ & $15,5 \%$ \\
\hline $\begin{array}{l}\text { What language does } \\
\text { your teacher often } \\
\text { use for explaining } \\
\text { material? }\end{array}$ & $22,4 \%$ & $37,9 \%$ & $1,7 \%$ & $0 \%$ & $37,9 \%$ \\
\hline $\begin{array}{l}\text { What language does } \\
\text { your teacher often } \\
\text { use for giving } \\
\text { exercise? }\end{array}$ & $27,6 \%$ & $41,4 \%$ & $0 \%$ & $0 \%$ & $31 \%$ \\
\hline $\begin{array}{l}\text { What language does } \\
\text { your teacher often }\end{array}$ & $19 \%$ & $44,8 \%$ & $1,7 \%$ & $0 \%$ & $34,5 \%$ \\
\hline
\end{tabular}




\begin{tabular}{|c|c|c|c|c|c|}
\hline $\begin{array}{l}\text { use for discussing } \\
\text { the material? }\end{array}$ & & & & & \\
\hline $\begin{array}{l}\text { What language does } \\
\text { your teacher often } \\
\text { use for } \\
\text { communicating in } \\
\text { EFL classroom? }\end{array}$ & $15,5 \%$ & $50 \%$ & $3,4 \%$ & $1,7 \%$ & $29,3 \%$ \\
\hline $\begin{array}{l}\text { What language does } \\
\text { your teacher often } \\
\text { use for closing the } \\
\text { lesson? }\end{array}$ & $32,8 \%$ & $29,3 \%$ & $1,7 \%$ & $3,4 \%$ & $32,8 \%$ \\
\hline $\begin{array}{l}\text { What language do } \\
\text { you often use to } \\
\text { your English } \\
\text { teacher If you had a } \\
\text { question? }\end{array}$ & $22,4 \%$ & $46,6 \%$ & $5,2 \%$ & $1,7 \%$ & $24,1 \%$ \\
\hline $\begin{array}{l}\text { What language do } \\
\text { you often use to } \\
\text { answer the question } \\
\text { If the teacher asked } \\
\text { you? }\end{array}$ & $24,1 \%$ & $46,6 \%$ & $6,9 \%$ & $0 \%$ & $22,4 \%$ \\
\hline $\begin{array}{l}\text { What language do } \\
\text { you often use for } \\
\text { discussing the } \\
\text { material with your } \\
\text { friends? }\end{array}$ & $15,5 \%$ & $36,2 \%$ & $25,9 \%$ & $1,7 \%$ & $20,7 \%$ \\
\hline $\begin{array}{l}\text { What language do } \\
\text { you often use to } \\
\text { communicate with } \\
\text { your friends in the } \\
\text { EFL Classroom? }\end{array}$ & $13,8 \%$ & $41,4 \%$ & $36,2 \%$ & $0 \%$ & $13,8 \%$ \\
\hline Average & $24,7 \%$ & $40,4 \%$ & $8,4 \%$ & $0,9 \%$ & $26,2 \%$ \\
\hline
\end{tabular}

Based on the table above, it can be concluded that teacher and students mostly used Indonesian in EFL classroom interaction. It is shown by students' answer that $50 \%$ of teacher used Indonesian, 29,3\% mix language, 15,5\% used English, 3,4\% used Banjarese, and 1,7\% used Dayakese for communicating in EFL classroom. The teacher mostly used English (54\%) when opening the lesson. For explaining the material, the teacher mostly used Indonesian and mix the language (37,9\%) and for giving the exercise they mostly used Indonesian (41,4\%). In discussing material, the teacher mostly used Indonesian $(44,8 \%)$ and for closing the lesson the teacher mostly used English or mix language (32,8\%).

For students, $46,6 \%$ mostly used Indonesian when they asked a question or answered it to the teacher. Meanwhile, more than 20\% used English and mix language but less than 10\% used the local language (Banjarese and Dayakese). For discussing the material, 36,2\% of students used Indonesian, while 25,9\% used Banjarese, 20,7\% mix language, and 1,7\% used Dayakese. They also mostly used Indonesian $(41,4 \%)$ for communicating with their friends in EFL classroom. Some of them used Banjarese (36,2\%) and the others using English and mix the language (13,8\%). So, on average, $24,7 \%$ of teacher and students used English, 40,4\% used Indonesian, 8,4\% used 
Banjarese, $0,9 \%$ used Dayakese, and 26,2\% mixed the language or used code-switching and codemixing in EFL classroom interaction. The use of local language is often used when they communicated with their friends in the EFL classroom.

Teacher's view

There are some questions to the teacher related to the language use in EFL classroom interaction during the teaching and learning process. She said mostly used code-switching and code-mixing in her EFL classroom interaction. It is because most students have less ability in English. Sometimes she used local language to gain students' understanding of what she had said. There are some languages which is used by the teacher in her EFL classroom interaction.

\section{Banjarese language}

Banjarese language is the language spoken by the Banjar tribe in South Kalimantan, some experts argue that the Banjarese language belongs to the East Borneo Malay language group. The Banjarese language is divided into two major dialects, namely the Banjar Kuala dialect (BBK) and the Banjar Hulu dialect (BBH). The BBK dialect is generally used by indigenous people around the cities of Banjarmasin, Martapura, Pelaihari, and Kotabaru, while BBH is generally used by residents in upstream areas such as Tapin Regency, Hulu Sungai Selatan, Hulu Sungai Tengah, Hulu Sungai Utara, and Tabalong Regency.

The Banjarese language is used by people who live in South Kalimantan as a communicative language. Apart from that, the Banjarese language is also a native speakers' pride, regional symbols, and a unifying tool among speakers. In their daily interactions, the Banjar people often mix with other tribes around them, namely the Dayakese, Javanese, and Madurese. As a result of the association of the Banjar tribe with other tribes, the Banjarese language has been influenced by the various regional languages around it.

In Central Kalimantan especially at Katingan Regency, for Dayak people, they use Banjar language with Dayak dialect. In the classroom context at MAN Katingan, the teacher sometimes used Banjarese to interact with the students. See the following example:

Teacher : Ayu lakas, sudah kah balum? (Come on, have you finished?)

Students : Balum, Ms (Not yet, Ms)

\section{Dayakese language}

The Dayakese language is the native language of the Dayak tribe which is spoken by the large Dayak Ngaju tribe and other tribes in Central Kalimantan. This province use the same language, but due to differences in places and there has been a change in vocabulary to the influence of other languages in surroundings, and especially there are differences dialect, but generally they can be understood easily.

Most of Dayak tribe in Katingan using Dayak Ngaju language. Durasid, et al in Charolina (2020) stated that the Dayak Ngaju language has 3 types of dialects, namely Kahayan Kapuas Ngawa (Kahayan Kapuas Hilir), Kahayan Ngaju (Kahayan Hulu), and Kapuas Ngaju. As the native language of the Dayak people, of course, Dayakese language is the main language that is mastered and used first daily in family and social circles. The use of Dayakese language occurs when the Dayakese ethnic talked to their same ethnicity. This is an example of an utterance between teacher and students using Dayak language in EFL classroom interaction.

Teacher : Silvi, narai materi je nenge itah minggu helu? (Silvi, what is our previous 
material?)

Student : Dia ingat te, Ms. (I am forget, Ms)

\section{Code-switching}

Suwito (1985: 68) in Fanani \& Ma'u (2018) stated code -witching is a transition event from one code to another. If a speaker initially uses code A (for example Indonesian), then switches to using code B (for example Javanese), then a language switching event is called code switching. Code switching can be in the form of style code-switching, variations, and other language variations. Code-switching can also be defined by switching or moving a form of speech from one language to another, or from one variation to another, or from one dialect to another, Subroto in (Hasan, 2014). Deliberately or intentionally switching the code on generally occurs for a specific reason and certain motivation to achieve its goals.

Susmita (2015) as citied in Ohoiwutun stated that code-switching is essentially a change in the use of language or dialect. The reference is the language community (dialect). It can be said that code-switching (language or dialect) is carried out by two parties who have the same two language communities. Code-switching only occurs in one language and one community.

Nababan stated that the concept of code switching also includes events when we switch from one language type, for example, the formal variety to another, for example the familiar variety; or from one dialect to another; or from a high level of speech, for example Kromo Inggil (Javanese) to a lower speech, for example, Ngoko, and so on. Code-switching can occur in bilingual or multilingual language communities, but also occurs in monolingual language communities. (Charolina, 2020)

People who do not have a good understanding of the language can never convert the code of the language. However, most code-switching are spontaneous and are mainly noticed. In addition, code-switching is an alternative to bilingualism in two or more languages in the same conversation; therefore, code-switching appears in second language classrooms. For example, in school English classes, English and the first language (also called mother tongue) are often interchanged. In the EFL classroom, code-switching began to be used in the words of teachers or students. This is a phenomenon widely observed in multilingual and multicultural communities, especially in Foreign language teaching.(Novianti \& Said, 2021)

Based on the explanation of several experts regarding code-switching, it can be concluded that code-switching is a transfer of language or a variety of languages carried out by speakers in a speech act. Here is the example of conversation using codeswitching in EFL classroom interaction:

Teacher : Very good students, ada yang bisa menambahkan? (any other ?) Eweh je maingat tau angkat lenge ah. (please rise your hand if you know the answer) Come on..

Students : Saya Bu (Me), But I still confused.

Teacher : Nevermind, gak papa jawab aja.

From the conversation above, the teacher switch language from English to Indonesian and Dayak language. While, the students switch language from Indonesian to English to answer the teacher's question. They use codeswitching because they master on that languages.

\section{Code mixing}

Another Phenomenon related to bilingualism and multilingualism is called code mixing. It is a phenomenon that occurs when someone change one language to another $\mathrm{n}$ the same sentence without changing the meaning. It occurs when words, affixes, phrases, and clauses are used in the 
same sentence in the same time (Novianti \& Said, 2021). Based on the statement before, definition of code mixing can be explained as:

1. Make code mixing without changing the theme

2. Words are borrowed from one language and adapted to another language

3. Code mixing is a phenomenon of language contact, which cannot reflect the grammar of two languages working at the same time.

4. Appears within a sentence, one component is the spoken language of language $\mathrm{A}$, and the rest is the spoken language of language $\mathrm{B}$

5. The word usually exists mainly in informal interactions

In our daily lives, sometimes we communicate with other people whose languages are different from ours. Language differences may become one of the obstacles in the process of social communication. When achieving goals, communicating in the group community and the classroom is the most important and basic thing. It is designed to make the interlocutor immediately understand what we are saying and the code mix in specific studies in foreign language learning. See the example below:

Teacher: Ayo di-mix aja dengan bahasa Indonesia Students: Maaf Ms, saya sudah nge-blank

From the conversation above, we can see that teacher and students mixing two or more languages into a structure of the other language usually consists of words and phrases. The word "mix" and "blank" is sentence is the English word inserted into the Indonesian utterance.

\section{Discussion}

Based on the findings, the used of L1 (Bahasa Indonesia) is dominated in the teaching and learning process. For students, the use of $\mathrm{L} 1$ gives them an advantage in comprehending the materials, adding their vocabulary and giving them opportunities to master their L2 by using their L1. When they can understand the materials given, it will be easier for them to get the objectives of their learning in the classroom; they can learn fast and well.(Sulistiyo et al., 2017)

Littlewood and $\mathrm{Yu}$ as citied in Mohebbi \& Alavi (2014) point out teachers use L1 to establish social relationships in the classroom, emphasizing the main points of the course, ensuring that students understand the courses being taught, and saving time. In addition, Haryanto \& Mukminin (2012) proposed that when students do not understand what the teacher explains in English, students are more willing to use L1 (Indonesian) in the classroom. The teachers use L1 mainly to provide feedback, explain grammar, teach new vocabulary, help learners individually, and effectively manage the classroom (Mohebbi \& Alavi, 2014).

Although Bahasa gives them some advantages in such a way, as EFL students, it is better for them to use more English in their EFL classroom interaction. The use of Bahasa may not help to improve their ability well. Some students also state that English provides many advantages for them. It helps them to develop their knowledge and experiences using English. More, it also helps them to add their new vocabulary. Having English as the medium of instruction in their EFL classroom interaction can be a good habit for them to practice speaking and communicating in English.

Therefore, using L1 in an L2 classroom does require the teacher to be flexible. They may still use L1, but don't overuse it. The teachers should be proactive in the classroom. This means 
that teachers should control and influence how and when to use L1 in the classroom. Teachers should be able to use L1 and decide when using L1 can benefit the teaching process. Even if he/she thinks it will be helpful, the lecture may explain her/his choice to the student. If the teacher can do this, the second language classroom can become a more realistic place to play L1 and L2.(Voicu, 2012)

On the other hand, the teacher stated mostly used code-switching and code mixing or sometimes used local language in EFL classroom interaction. It is because the students have less ability in English. So, the teacher used code-switching to gain students' understanding of what she had explained. She switched languages, English to Indonesian or vice versa or sometimes to their local languages such as Dayakese or Banjarese. Classroom code-switching is a natural and expected practice of students and teachers who share a common first language. In other words, when the code switching is performed, the native language may come to the student to acquire their ability.

From the phenomenon above, the researchers assumes that the use of code-switching as communication strategies by EFL learners is cognitively common and cannot be avoided. The main purpose of using code switching is to be able to communicate, even with limited target language competence, both in grammatical and vocabulary aspects.(Fauziati et al., 2020)

\section{Conclusion}

In the social context, language is not only a means of communication but also an important means of establishing and maintaining social relations between one person and another. For example, there are two people don't know each other in a given public place. They started talking to ask for some information. They are telling their stories. In this relationship, they use language as a means of communication and at the same time as a means of establishing social relationships. The next time, it can be used as a means to maintain their social relations.

In the EFL classroom interaction, the use of language at MAN Katingan is varied enough. Therefore, MAN Katingan is a multilingual. English teachers used English, Indonesian and local language in English teaching and learning process. If teachers and students interact in the different language in teaching and learning process, then the code-mixing and codeswitching in the classroom cannot be ignored. Perhaps, in further research, the researcher will conduct the research about codeswitching and codemixing analysis which is used by them.

Declaration of conflicting interest

The authors state that there is no conflict of interest concerning the publication of this paper.

Funding acknowledgement

The authors received no financial support for the research, authorship, and/or publication of this article.

\section{References}

Asrifan, A. (2021). Code Mixing and Code Switching in the Efl Classroom Interaction. LawArxiv Papers, 1-31.

Charolina, C. (2020). Pilihan Bahasa Masyarakat Bilingual Banjar-Dayak di Palangka Raya Dalam Ranah Keluarga. Tesis.

Fanani, A., \& Ma'u, J. A. R. Z. (2018). Code switching and code mixing in English learning process. LingTera, 5(1), 68-77. https://doi.org/10.21831/lt.v5i1.14438 
Fauziati, E., Widiastuti, H., \& Darussalam, M. (2020). CODE SWITCHING AS INTERLANGUAGE COMMUNICATION STRATEGY BY INDONESIAN EFL LEARNERS. 9, 301-311.

Haryanto, E., \& Mukminin, A. (2012). Global, National, and Local Goals: English Language Policy Implementation in an Indonesian International Standard School. Excellence in Higher Education, 3(2), 69-78. https://doi.org/10.5195/ehe.2012.66

Hasan, K. (2014). Reviewing the Challenges and Opportunities Presented by Code Switching and Mixing in Bangla. Journal of Pan-Pacific Association of Applied Linguistics (Journal of PAAL ), 18(2), 63-75.

Hill, J. C. (2015). Data Collection in Sociolinguistics. In Research Methods in Sign Language Studies. https://doi.org/10.1002/9781118346013.ch12

Mohebbi, H., \& Alavi, S. M. (2014). 290874-402900-1-Pb. 7(4), 57-73.

Mu'in, F. (2019). SOCIOLINGUISTICS: A Language Study in Sociocultural Perspectives. 308.

Muin, F. (2019). Language Use In Lok Baintan Floating Market of Banjar District of South Kalimantan. Indonesian Journal of Cultural and Community Development, 2(November 2019). https://doi.org/10.21070/ijccd.v2i1.56

Novianti, R., \& Said, M. (2021). The Use of Code-Switching and Code-Mixing in English Teaching-Learning Process. Deiksis, 13(1), 82. https://doi.org/10.30998/deiksis.v13i1.8491

Sharaeai, W. (2012). Students' Perspectives on the Use of L1 in English Classrooms. 1-113. http://lib.dr.iastate.edu/etd/12898/

Snorrad, B. (2014). Language use in the English classroom. 65.

Sulistiyo, U., Haryanto, E., \& Wulan, W. (2017). EFL Pre-Service Teachers' Perception of Language Use for Medium of Instruction in English Classroom. 82(Conaplin 9), 318-321. https://doi.org/10.2991/conaplin-16.2017.73

Surayatika, D. (2020). Students' Perception of Teachers' Bilingual Language Use in EFL Classroom. Global Expert: Jurnal Bahasa Dan Sastra, 8(2), 45-51. https://doi.org/10.36982/jge.v8i2.963

Susmita, N. (2015). Alih Kode dan Campur Kode dalam Pembelajaran Bahasa Indonesia di Smp Negeri 12 Kerinci. Jurnal Penelitian Jambi Seri Humaniora, 17(2), 87-98. https://www.neliti.com/id/publications/43500/alih-kode-dan-campur-kode-dalampembelajaran-bahasa-indonesia-di-smp-negeri-12-k

Voicu, C. G. C. G. (2012). Overusing mother tongue in English language teaching. International Journal of Communication Research, 2(3), 212-218. 